\title{
Modulation of $\mathbf{T}_{4} 5^{\prime}$-Monodeiodination in Rat Anterior Pituitary and Liver Homogenates by Thyroid States and Fasting
}

\author{
Koichi NAITO, Mitsuo INADA, Yasuo MASHIO, KiYoshi TANAKA, \\ Hitoshi ISHII, Mitsushige NISHIKAWA AND Hiroo IMURA \\ Second Division, Department of Internal Medicine, \\ Kyoto University School of Medicine, Kyoto 606
}

\begin{abstract}
In order to clarify the role of the pituitary conversion of L-thyroxine $\left(\mathrm{T}_{4}\right)$ to 3 , $5,3^{\prime}$-L-triiodothyronine $\left(\mathrm{T}_{3}\right)$ in regulating thyrotropin (TSH) secretion, the effect of altered thyroid states and fasting on intrapituitary $T_{3}$ generation was investigated by a paperchromatographic procedure using the anterior pituitary homogenates. Hepatic $\mathrm{T}_{3}$ generation was also studied for comparison.

The rate of pituitary and hepatic $\mathrm{T}_{3}$ generation in normal rats averaged $25.2 \pm$ 12.4 (mean $\pm \mathrm{SE}$ ) fmoles $\mathrm{T}_{3} / \mathrm{mg}$ protein $/ \mathrm{min}$ and $33.8 \pm 12.7$ fmoles $\mathrm{T}_{3} / \mathrm{mg}$ protein $/ \mathrm{min}$, respectively. $\quad T_{4}$ treatment raised the hepatic $T_{3}$ generation from $T_{4}(46.7 \pm 3.1$ fmoles $\mathrm{T}_{3} / \mathrm{mg}$ protein $\left./ \mathrm{min}\right)$ and lowered the intrapituitary $\mathrm{T}_{3}$ generation $\left(4.5 \pm 0.2 \mathrm{fmoles} \mathrm{T}_{3} /\right.$ $\mathrm{mg}$ protein $/ \mathrm{min}$ ). On the contrary, thyroidectomy slowed the hepatic $\mathrm{T}_{4} 5^{\prime}$-deiodination $\left(11.0 \pm 2.8 \mathrm{fmoles} \mathrm{T}_{3} / \mathrm{mg}\right.$ protein $\left./ \mathrm{min}\right)$, and accelerated the pituitary $\mathrm{T}_{4} 5^{\prime}$ deiodination $\left(64.3 \pm 1.4 \mathrm{fmoles} \mathrm{T}_{3} / \mathrm{mg}\right.$ protein $\left./ \mathrm{min}\right)$. In $48 \mathrm{~h}$ fasted rats, serum $\mathrm{T}_{4}, \mathrm{~T}_{3}$ and TSH concentrations were all lower than those in fed rats, and both pituitary and hepatic $\mathrm{T}_{3}$ generations were also suppressed.

Thus, altered thyroid states cause an opposite effect on pituitary and liver 5'monodeiodination, whereas fasting causes similar changes. The findings suggest the existence of an autoregulatory mechanism for thyroid hormone activation within the target tissues.
\end{abstract}

Recent studies have demonstrated in vitro $3,5,3^{\prime} \mathrm{L}$-triiodothyronine $\left(\mathrm{T}_{3}\right)$ generation from L-thyroxine $\left(\mathrm{T}_{4}\right)$ in rat anterior pituitary fragments (Silva et al., 1978a) and homogenates (Kaplan, 1980). The $\mathrm{T}_{4} 5^{\prime}$ monodeiodination in the pituitary was temperature- and $\mathrm{pH}$-dependent and thiol sensitive, suggesting that the activity is enzymatic in nature (Kaplan, 1980).

Recently, we investigated the age-related changes in $\mathrm{T}_{4} 5^{\prime}$-monodeiodination in rat pituitary and liver homogenates, and observed the difference between maturational patterns in rat anterior pituitaries and livers (Naito et al., 1980). Moreover, a reci- procal relation between serum thyrotropin (TSH) levels and intrapituitary $\mathrm{T}_{3}$ generating activity from $T_{4}$ was demonstrated in the perinatal rats, suggesting an important role of the local $T_{3}$ production in regulating pituitary $\mathrm{TSH}$ secretion. These results essentially agree with those observed by El-Zaheri et al. (1980) and Cheron et al. (1980).

In order to explore the further role of the pituitary $T_{3}$ generation from $T_{4}$, the effect of the thyroid state and fasting on intrapituitary $T_{3}$ production was examined in the present experiment.

Received October, 8, 1981. 


\section{Materials and Methods}

Male Wistar rats, weighing about $300-400 \mathrm{~g}$, were used in all experiments. To study the effect of altered thyroid states, rats were either thyroidectomized or treated with sc injection of $\mathrm{T}_{4}(10 \mu \mathrm{g} / 100 \mathrm{~g}$ $\mathrm{BW}$ ) for 5 days. The thyroidectomized rats were maintained on $0.5 \% \mathrm{CaCl}_{2}$ water ad libitum for at least 2 weeks before the experiment, and the $\mathrm{T}_{4}$ treated rats were used for the experiments $24 \mathrm{~h}$ after the last injection. In fasting studies, rats were deprived of food for $48 \mathrm{~h}$ with free access to water. Control rats were sacrificed at the same time as treated rats and the controls for $\mathrm{T}_{4}$-treated rats were injected with the drug vehicle. All rats were maintained in a temperature- and light-controlled room ( $12 \mathrm{~h}$ of light and $12 \mathrm{~h}$ of dark).

$\mathrm{L}-\left[3^{\prime}, 5^{\prime}-125 \mathrm{I}\right]-\mathrm{T}_{4}$ was prepared by the chlolamine $T$ method (Burger and Ingbar, 1974) and its specific activity was $580-850 \mu \mathrm{Ci} / \mu \mathrm{g}$. Radioactive $\mathrm{T}_{4}$ was free from appreciable contaminants other than approximately $6 \%$ iodide as tested by paperchromatography (Bellabarba et al., 1968) and electrophoresis (Inada and Sterling, 1967). The rats were sacrificed by decapitation and the anterior pitcitary and liver were dissected. Trunk bood was collected to determine serum $\mathrm{T}_{4}, \mathrm{~T}_{3}$ and $\mathrm{TSH}$ concentrations. Details of preparation of homogenates and incubation procedures were described in the previous paper (Naito et al., 1981). In brief, homogenates of the tissues were prepared in $15 \mathrm{vol}$. (wt/vol) of cold $0.05 \mathrm{M}$ Tris-sucrose buffer, $\mathrm{pH} 7.6$ and incubated with ${ }^{125} \mathrm{I}_{-} \mathrm{T}_{4}$ (approximately $3-5$ pmoles), $0.1 \mu \mathrm{M}$ unlabeled $\mathrm{T}_{4}$ and Tris-sucrose buffer, $\mathrm{pH} 7.6$ to yield a final volume of $0.5 \mathrm{ml}$ in the presence of dithiothreitol (DTT). The DTT concentrations employed in the present study were $5 \mathrm{~mm}$ for the liver homogenates and $50 \mathrm{~mm}$ for the pituitary homogenates. After the incubation, ethanol extraction of the incubation mixture was carried out. An aliquot of the ethanol extract was applied to paper, with a carrier amount of iodide, $\mathrm{T}_{4}$ and $\mathrm{T}_{3}$, and subjected to descending paperchromatography in the t-amylalcohol-2N ammonia-hexane $(10: 11: 1)$ solvent (Bellabarba et al., 1968). The amount of $\mathrm{T}_{3}$ formed was calculated from the conversion ratio from $T_{4}$ to $T_{3}$ and $\mathrm{T}_{4}$ amount in the incubation mixture. Protein content was determind by the method of Lowry et al. (1951), and $T_{3}$ generation was expressed as fmoles $\mathrm{T}_{3} / \mathrm{mg}$ protein $/ \mathrm{min}$.

TSH levels in rat serum were determined with a radioimmunoassay kit which was generously supplied by the NIAMDD of the NIH, USA (Naito et al., 1981). $T_{4}$ and $T_{3}$ levels in rat serum were also measured by radioimmunoassay kits provided by Dainabot Radioisotope Laboratories, Chiba, Japan (Naito et al., 1981).
All experiments were made in duplicate. Results are expressed as the mean $\pm \mathrm{S}$. E. Comparison between groups were performed using Student's $t$ test for unpaired values.

\section{Results}

As shown in Table 1 , serum $T_{4}$ and $T_{3}$ concentrations in rats injected with $\mathrm{T}_{4}$ were elevated, being $200 \%$ and $136 \%$, respectively, of the control values, whereas serum TSH concentrations were undetectable. In contrast, the thyroidectomized rats had difinitely low serum $\mathrm{T}_{4}$ and $\mathrm{T}_{3}$ concentrations with markedly elevated serum TSH levels (Table 1).

The effect of altered thyroid states on $\mathrm{T}_{3}$ generation in rat anterior pituitary and liver is shown in Fig. 1. The rates of pituitary and hepatic $T_{3}$ generation averaged $25.5 \pm 12.4 \mathrm{fmoles} \mathrm{T}_{3} / \mathrm{mg}$ protein $/ \mathrm{min}$ and $33.8 \pm 12.7$ fmoles $\mathrm{T}_{3} / \mathrm{mg}$ protein $/ \mathrm{min}$, respectively, in normal rats. In $T_{4}$-treated rats, however, the elevation of hepatic $T_{3}$ generation from $\left.\mathrm{T}_{4}\right)\left(46.7 \pm 3.1\right.$ fmoles $\mathrm{T}_{3} / \mathrm{mg}$ protein $/ \mathrm{min}$ ) was found, whereas intrapituitary $\mathrm{T}_{3}$ generation was markedly decreased ( $4.5 \pm 0.2$ fmoles $T_{3} / \mathrm{mg}$ protein $/ \mathrm{min}$, Fig. 1). On the other hand thyroidectomized rats had slower hepatic $\mathrm{T}_{4} 5^{\prime}$-monodeiodination (11.0 \pm 2.8 fmoles $T_{3} / \mathrm{mg}$ protein $/ \mathrm{min}$ ), and accelerated intrapituititary $\mathrm{T}_{4} 5^{\prime}$-monodeiodination $\left(64.3 \pm 1.4\right.$ fmoles $\mathrm{T}_{3} / \mathrm{mg}$ protein $/ \mathrm{min}$, Fig. 1) than the controls, showing opposite changes in hyper- and hypothyroid rats (Fig. 1).

As shown in Table 2, $48 \mathrm{~h}$-fasted rats had lower serum $\mathrm{T}_{4}(3.4 \pm 0.6 \mu \mathrm{g} / \mathrm{dl}), \mathrm{T}_{3}$ $(70.0 \pm 12.5 \mathrm{ng} / \mathrm{dl})$ and $\mathrm{TSH}(38 \pm 12.3 \mathrm{ng} /$ $\mathrm{m} l$ ) levels, compared with fed rats. Table 2 also shows that fasting for $48 \mathrm{~h}$ led to a $75 \%$ decrease in $\mathrm{T}_{4}$ to $\mathrm{T}_{3}$ conversion activity in the liver $(\mathrm{p}<0.01)$. Similarly, fasting resulted in a $74 \%$ reduction in pituitary $\mathrm{T}_{3}$ generation even in the presence of $50 \mathrm{~mm}$ DTT $(\mathrm{p}<0.05)$. 
Table 1. Serum concentrations of $\mathrm{T}_{4}, \mathrm{~T}_{3}$ and $\mathrm{TSH}$ in thyroid hormone excess and deficiency.

\begin{tabular}{ccccc}
\hline \hline & $\begin{array}{c}\mathrm{T}_{4}(\mu \mathrm{g} / \mathrm{d} l) \\
\text { mean } \pm \text { S.E. }\end{array}$ & $\begin{array}{c}\mathrm{T}_{3}(\mathrm{ng} / \mathrm{d} l) \\
\text { mean } \pm \text { S.E. }\end{array}$ & $\begin{array}{c}\mathrm{TSH}(\mathrm{ng} / \mathrm{m} l) \\
\text { mean } \pm \mathrm{S} . \mathrm{E} .\end{array}$ \\
\hline a. $\quad \mathrm{T}_{4}$ treated rats (4) & $6.3 \pm 0.6$ & $127 \pm 15.3$ & $\begin{array}{c}\text { under limit of } \\
\text { determination }\end{array}$ \\
& $\mathrm{P}$ & $<0.05$ & $<0.025$ & \\
b. thyroidectomized rats (4) & $1.3 \pm 0.4$ & $67.3 \pm 15.5$ & $1300 \pm 550$ \\
& $\mathbf{P}$ & $<0.005$ & $<0.05$ & $<0.005$ \\
c. normal rats (4) & $3.1 \pm 0.3$ & $93.7 \pm 17.0$ & $159 \pm 54$ \\
\hline
\end{tabular}

Numbers in parenthesis represent the number of rats in each group.

P: Probability that the values in $\mathrm{T}_{4}$ treated rats or thyroidectomized rats are identical to the corresponding values in normal rats.

Table 2. Effect of $48 \mathrm{~h}$ starvation on serum concentrations of $\mathrm{T}_{4}, \mathrm{~T}_{3}$ and $\mathrm{TSH}$ and on $\mathrm{T}_{3}$ generation from $\mathrm{T}_{4}$ in rat anterior pituitary and liver.

\begin{tabular}{ccccccc}
\hline & \multicolumn{3}{c}{ Serum concentration } & & \multicolumn{2}{c}{$\begin{array}{c}\mathrm{T}_{3} \text { generation from } \mathrm{T}_{4} \\
\text { (fmoles } \mathrm{T}_{3} / \mathrm{mg} \text { protein } / \text { min) }\end{array}$} \\
\cline { 2 - 4 } Treatment & $\mathrm{T}_{4}(\mu \mathrm{g} / \mathrm{d} l)$ & $\mathrm{T}_{3}(\mathrm{ng} / \mathrm{d} l)$ & $\mathrm{TSH}(\mathrm{ng} / \mathrm{m} l)$ & & Liver & Pituitary \\
& mean $\pm \mathrm{SE}$ & mean $\pm \mathrm{SE}$ & mean $\pm \mathrm{SE}$ & & mean $\pm \mathrm{SE}$ & mean $\pm \mathrm{SE}$ \\
\hline Fed (5) & $4.4 \pm 0.9$ & $91.8 \pm 20.9$ & $134 \pm 41.8$ & & $46.5 \pm 4.9$ & $35.7 \pm 2.2$ \\
Fasted (5) & $3.4 \pm 0.6$ & $70.0 \pm 12.5$ & $38 \pm 12.3$ & & $34.9 \pm 0.3$ & $26.6 \pm 5.5$ \\
$\mathbf{P}$ & $<0.05$ & $<0.05$ & $<0.01$ & & $<0.01$ & $<0.05$ \\
\hline
\end{tabular}

Numbers in parenthesis represent the number of rats in each group.

P: Probability that the values in fasted rats are identical to the corresponding values in fed rats.

\section{Dscussion}

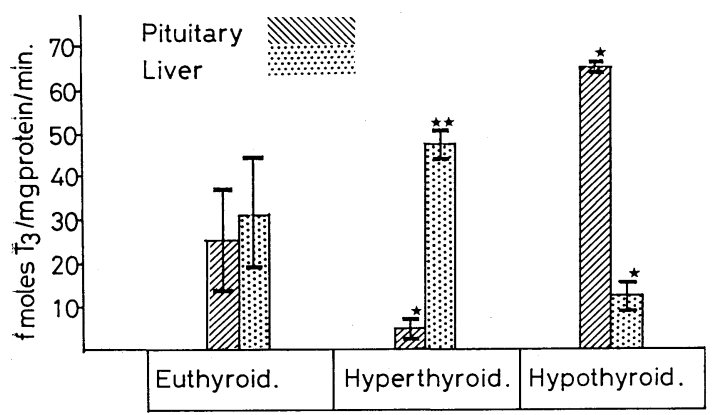

Fig. 1. Effect of thyroid hormone excess and deficiency on $T_{3}$ generation from $T_{4}$ in the rat anterior pituitary and liver. Each bar represents the mean \pm S.E. The DTT concentrations in the incubation mixtures were $50 \mathrm{mM}$ for the pituitary homogenates and $5 \mathrm{mM}$ for the liver homogenates.

Euthyroid: normal rats

Hyperthyroid: $\mathrm{T}_{4}$-treated rats

Hypothyroid: thyroidectomized rats

$* \mathbf{P}<0.01 \quad * * \mathbf{P}<0.05$
$\mathrm{T}_{4} 5^{\prime}$-monodeiodinating activity has been demonstrated in rat liver (Visser et al., 1976; Chopra, 1978; Kaplan and Utiger, 1978), Kidney (Chiraseveenuprapund et al., 1978; Leonard and Rosenberg, 1978), anterior pituitary (Silva et al., 1978a; Kaplan, 1980), thyroid (Erickson et al., 1981) and brain (Kaplan and Yaskoski, 1980) and in human thyroid (Ishii et al., 1981). These studies have shown that the $\mathrm{T}_{4} 5^{\prime}$-deiodinating activity is enzymatic in nature. It has also been demonstrated that some physiological alterations or pharmacological agents alter $\mathrm{T}_{3}$ generation from $\mathrm{T}_{4}$ in different ways in various tissues (Larsen et al., 1981). In hypothyroid rats, hepatic and renal $\mathrm{T}_{3}$ generation was decreased (Larson et al., 1955; Grussendorf and Hüfner, 1977; Harris et al , 1978; Balsam et al., 1978; Ka- 
plan and Utiger, 1978), while the rates in the pituitary (Kaplan, 1980) and brain (Kaplan and Yaskoski, 1980) were increased. On the other hand, the opposite changes occurred in hyperthyroid rats. The present study confirmed these previous observations, using rat liver and anterior pituitary homogenates. These findings suggest the presence of an autoregulatory mechanism of thyroid hormone activation within the target tissues.

In the previous study, we observed the reciprocal relationship between the pituitary $\mathrm{T}_{3}$ generation and serum TSH level in perinatal and young adult rats (Natio et al., 1981). This agrees with the postulate that the local $T_{3}$ production in rat anterior pituitary plays an important role in regulating TSH secretion (Silva and Larsen, 1977; Larsen et al., 1979; Obregon et al., 1980). In the present paper, however, pituitary $T_{3}$ generation rather increased in thyroidectomized rats which had markedly elevated TSH levels in serum, while they decreased in $\mathrm{T}_{4}$-treated rats with suppressed TSH levels. It has been generally accepted that $\mathrm{T}_{3}$ exerts its effect by first binding to specific receptors located in the cell nucleus $(\mathrm{Op}$ penheimer et al., 1976). Since nuclear $T_{3}$ in the anterior pituitary is derived from two sources, circulating $\mathrm{T}_{3}$ and intracellular $\mathrm{T}_{3}$ generated from $\mathrm{T}_{4}$, Silva et al. (1978b) estimated the relative contributions of $T_{3}$ from two sources to nuclear $\mathrm{T}_{3}$. They concluded that approximately $50 \%$ of specifically bound nuclear $\mathrm{T}_{3}$ is derived from intrapituitary $\mathrm{T}_{4} 5^{\prime}$-monodeiodination in normal rats. In the present study, serum $\mathrm{T}_{3}$ concentrations in the thyroidectomized rats were almost two thirds those in normal rats and $T_{3}$ generation in the pituitary was accelerated, while serum TSH levels were elevated. On the other hand, $135 \%$ elevation of serum $\mathrm{T}_{3}$ along with a decreased pituitary $\mathrm{T}_{4}$ concentration was associated with low serum TSH levels in hyperthyroid rats. Although the contribution of circulating $T_{3}$ to nuclear $\mathrm{T}_{3}$ in rat anterior pituitary was not estimated in thyroid hormone excess and deficiency, the results mentioned above suggest that circulating $T_{3}$ in thyroidectomized and $\mathrm{T}_{4}$-treated rats might contribute to nuclear $T_{3}$ more than $T_{3}$ generated locally from $\mathrm{T}_{4}$. An alterate explanation is that altered TRH secretion from the hypothalamus might change the threshold of the negative feedback effect of $\mathrm{T}_{3}$ on TSH secretion in hyer- and hypothyroid states.

It has been known that fasting causes a decrease in hepatic and pituitary $\mathrm{T}_{3}$ generation from $\mathrm{T}_{4}$ (Kaplan and Utiger, 1978; Campbell et al., 1977; Harris et al., 1978; Kaplan, 1980). Serum TSH levels as well as $\mathrm{T}_{4}$ and $\mathrm{T}_{3}$ concentrations were decreased in fasted rats (Kaplan and Utiger, 1978, Campbell et al., 1977; Harris et al., 1978). It is difficult to explain why serum TSH levels do not increase, despite decreased pituitary $T_{3}$ generation from $T_{4}$ and low serum $\mathrm{T}_{3}$ and $\mathrm{T}_{4}$ levels. Harris et al. (1978) and Campbell et al. (1979) observed that the responsiveness of TSH secretion to exogeneous TRH was maintained in fasted rats. On the basis of these observations, Gardner et al. (1979) suggested the decreased set point of TSH secretion in fasted rats. In other words, the critical level of serum thyroid hormone to induce an increase in TSH secretion is lowered by fasting. Our observation that decreased $T_{3}$ generation in pituitary in fasted rats is associated with low TSH levels can be explained by the decreased set point hypothesis, although the exact mechanism responsible for such a change is unknown.

The present study demonstrates a difference between the anterior pituitary gland and liver in the response of $\mathrm{T}_{4} 5^{\prime}$-monodeiodination to hypothyroid or hyperthyroid state. On the other hand, changes in pituitary and hepatic $T_{3}$ generation from $T_{4}$ were similar in fasted rats. The elucidation of factors responsible for such divergent changes will be of benefit in under- 
standing the nature of the feedback regulation of thyroid hormones on pituitary TSH secretion and clarifying characteristics of local $\mathrm{T}_{4} 5^{\prime}$-monodeiodionation in the anterior pituitary gland.

\section{References}

Balsam, A., F. Sexton and S. H. Ingbar (1978). The effect of thyroidectomy, hypophysectomy, and hormone replacement on the formation of triiodothyronine from throxine in rat liver and kidney. Endocrinology 103, 1759-1767.

Bellabarba, B., R. E. Peterson and K. Sterling (1968). An improved method for chromatography of iodothyronines. J. Clin. Endocrinol. Metab. 28, 305-307.

Burger, A. and S. H. Ingbar (1974). Labelling of thyroid hormones and their derivatives. Endocrinology 94, 1189-1196.

Campbell, G. A., M. Kurcz, S. Marshall and J. Meites (1977). Effect of starvation in rats on serum levels of follicle stimulating hormone, luteinizing hormone, thyrotropin, growth hormone, and prolactin response to LH-releasing hormone and thyrotropin releasing hormone. Endocrinology $100,580-587$.

Cheron, R. G., M. M. Kaplan and P. R. Larsen (1980). Divergent changes of thyroxine 5'-monodeiodination in rat pituitary and liver during maturation. Endocrinology 106, 1405-1409.

Chiraseveenuprapund, P., V. Buergi, A. Goswami and I. N. Rosenberg (1978). Conversion of Lthyroxine to triiodothyronine in rat kindey homogenates. Endocrinology 102, 612-622.

Chopra, I. J. (1978). Sulfhydryl groups and the monoiodination of thyroxine to triiodothyronine. Science 199, 904-906.

El-Zaheri, M., L. E. Braverman and A. G. Vagenakis (1980). Enhanced conversion of thyroxine to triiodothyronine by the neonatal rat pituitary. Endocrinology 106, 1735-1739.

Erickson, V. J., R. R. Cavalieri and L. L. Rosenberg (1981). Phenolic and nonphenolic ring iodothyronine deiodinases from rat thyroid gland. Endocrinology 108, 1257-1264.

Gardner, D. F., M. M. Kaplan, C. A. Stanley and R. D. Utiger (1979). Effect of tri-iodothyronine replacement on the metabolic and pituitary responses to starvation. N. Engl. J. Med. 300, 579584.

Grussendorf, M. and M. Hüfner (1978). Induction of the thyroxine to triiodothyronine converting enzyme in rat liver by thyroid hormones and analogs. Clin. Chim. Acta 80, 61-66.
Harris, A. R. C., S. L. Fang, F. Azizi, L. Lipworth, A. G. Vagenakis and L. E. Braverman (1978). Effect of starvation on hypothalamic-pituitarythyroid function in the rat. Metabolism 27, 10741083.

Inada, M. and K. Sterling (1967). Thyroxine turnover and transport in Laennec's cirrhosis of the liver. J. Clin. Invest. 46, 1275-1282.

Ishii, H., M. Inada, K. Tanaka, Y. Mashio, K. Naito, M. Nishikawa and H. Imura (1981). Triiodothyronine generation from thyroxine in human thyroid: Enhanced conversion in Graves' thyroid tissue. J. Clin. Endocrinol. Metab. 52, 1211-1217.

Kaplan, M. M. (1980). Thyroxine 5'-monodeiodination in rat anterior pituitary homogenates. Endocrinology 106, 567-576.

Kaplan, M. M. and R. D. Utiger (1978). Iodothyronine metabolism in rat liver homogenates. $J$. Clin. Invest. 61, 459-471.

Kaplan, M. M. and K. A. Yaskoski (1980). Phenolic and tyrosyl ring iodothyronine deiodination in rat brain homogenates. J. Clin. Invest. 66, 551-562.

Larsen, P. R., J. Dockalova, D. Sipulla and F. M. $\mathrm{Wu}$ (1973). Immunoassay of thyroxine in unextracted human serum. J. Clin. Endcrinol. Metab. 37, 177-182.

Larsen, P. R., T. E. Dick, B. P. Markovitz, M. M. Kaplan and T. G. Gard (1979). Inhibition of intrapituitary thyroxine to $3,5,3^{\prime}$-triiodothyronine conversion prevents the acute suppression of thyrotropin release by thyroxine in hypothyroid rats. J. Clin. Invest. 64: 117-123.

Larsen, P. R., J. E. Silva and M. M. Kaplan (1981). Relationships between circulating and intracellular thyroid hormones; Physiological and clinical implications. Endocr. Rev. 2, 87-102.

Larson, F. C., K. Tomita and E. C. Albright (1955). The deiodination of thyroxine to triiodothyronine by kidney slices of rats with varying thyroid function. Endocrinology 57, 338-344.

Leonard, J. L. and I. N. Rosenberg (1978). Thyroxine 5'-deiodinase activity of rat kidney: Observations on activation by thiols and inhibition by propylthiouracil. Endocrinology 103, 2137-2144.

Lowry, O. H., N. J. Rosenbrough, A. L. Farr and J. Randall (1951). Protein measurement with Folin phenol reagent. J. Biol. Chem. 193, 265-275.

Naito, K., M. Inada, Y. Mashio, K. Tanaka, H. Ishii, M. Nishikawa and H. Imura (1981). Reciprocal relation between serum thyrotropin levels and intrapituitary 3, 5, 3' L-triiodothyronine generating activities from thyroxine in perinatal rats. Endocrinol. Japon. 28, 461-468.

Obregon, M. J., A. Pascual, J. Mallol, G. Morreale de Escobar and F. Escobal del Rey (1980). Evidence against a major role of L-thyroxine at the pituitary level: Studies in rats treated with iopanoic acid (Telepaque). Endocrinology 106, 1827-1832.

Oppenheimer, J. H., H. L. Schwartz, M. I. Surks, 
D. Koerner and W. H. Dillman (1976). Nuclear receptors and the initiation of thyroid hormone action. Recent. Prog. Horm. Res. 32, 529-565.

Silva, J. E., M. M. Kaplan, R. G. Cheron, T. E. Dick and P. R. Larsen (1978a). Thyroxine to 3, 5, 3'-triiodothyronine conversion by rat anterior pituitary and liver. Metabolism 27, 1601-1607.

Silva, J. E., T. E. Dick and P. R. Larsen (1978b). The contribution of local tissue thyroxine monodeiodination to the nuclear 3, 5, 3'-triiodothyronine in pituitary, liver and kidney of euthyroid rats.
Endocrinology 103, 1196-1207.

Silva, J. E. and P. R. Larsen (1977). Pituitary nuclear 3, 5, 3'-triiodothyronine and thyrotropin secretion: an explanation for the effect of thyroxine. Science 198, 617.

Visser, T. J., I. Vander Does-Tobe, R. Docter and G. Henneman (1976). Subcellular localization of a rat liver enzyme converting thyroxine to triiodothyronine and possible involvement of essential thiol groups. Biochem. J. 157, 479-482. 